\title{
Assessing the greenhouse gas emissions from poultry fat biodiesel
}

\author{
Jørgensen, Andreas; Bikker, Paul; Herrmann, Ivan Tengbjerg
}

Published in:

Journal of Cleaner Production

Link to article, DOI:

10.1016/j.jclepro.2011.11.011

Publication date:

2012

Link back to DTU Orbit

Citation (APA):

Jørgensen, A., Bikker, P., \& Herrmann, I. T. (2012). Assessing the greenhouse gas emissions from poultry fat biodiesel. Journal of Cleaner Production, 24(March), 85-91. https://doi.org/10.1016/j.jclepro.2011.11.011

\section{General rights}

Copyright and moral rights for the publications made accessible in the public portal are retained by the authors and/or other copyright owners and it is a condition of accessing publications that users recognise and abide by the legal requirements associated with these rights.

- Users may download and print one copy of any publication from the public portal for the purpose of private study or research.

- You may not further distribute the material or use it for any profit-making activity or commercial gain

- You may freely distribute the URL identifying the publication in the public portal

If you believe that this document breaches copyright please contact us providing details, and we will remove access to the work immediately and investigate your claim. 


\title{
Assessing the Greenhouse Gas Emissions from Poultry Fat Biodiesel
}

Andreas Jørgensen ${ }^{\mathrm{a}}$, Paul Bikker ${ }^{\mathrm{b}}$, Ivan T. Herrmann ${ }^{\mathrm{c}}$

${ }^{a}$ Corresponding author. Department of Management Engineering, Section of Quantitative Sustainability Assessment, Technical University of Denmark, DK-2800, Kgs. Lyngby, Denmark, aj@man.dtu.dk, phone: +45 45254443

${ }^{\mathrm{b}}$ Wageningen UR Livestock Research, 6708 WC Wageningen, the Netherlands, paul.bikker@wur.nl

cAddress as ${ }^{\mathrm{a}}$, ithe@man.dtu.dk

\begin{abstract}
This article attempts to answer the question: What will most likely happen in terms of emitted greenhouse gases if the use of poultry fat for making biodiesel used in transportation is increased? Through a well-to-wheel assessment, several different possible scenarios are assessed, showing that under average conditions, the use of poultry fat biodiesel instead of diesel leads to a slight reduction (6\%) in greenhouse gas emissions. The analysis shows that poultry fat is already used for different purposes and using poultry fat for biodiesel will therefore remove the poultry fat from its original use. This implies that even though the use of biodiesel is assumed to displace petrochemical diesel, the 'original user' of the poultry fat will have to find a substitute, whose production leads to a greenhouse gas emissions comparable to what is saved through driving on poultry fat biodiesel rather than petrochemical diesel. Given that it is the production of the substitute for the poultry fat which mainly eliminates the benefit from using poultry fat for biodiesel, it is argued that whenever assessing the greenhouse gas emissions from biodiesel made from by-products (such as rendered animal fats, used cooking oil, etc.) it is very important to include the oil's alternative use in the assessment.
\end{abstract}

\section{Keywords}

Biodiesel; life cycle assessment; poultry fat; greenhouse gases

\section{Introduction}

Biodiesel has often been mentioned as a fuel with the potential for combating climate change. Many studies have been made to assess whether the substitution of petrochemical diesel with biodiesel will in fact lead to lower greenhouse gas (GHG) emissions over their complete life cycle, and the results depend, among others, on the oil used for the biodiesel production. One group of oils used for biodiesel is 'by-product' oils (BPO), which as the name indicate are oils produced as a by-product in various processes. BPO comprise for example used vegetable oils, used cooking oils, animal fat from rendering of animal carcasses, and yellow grease. Several studies have addressed environmental issues related to biodiesel from BPO (Beer et al. 2007, Jensen et al. 2007, López et al. 2010, Morais 2010, Montrimaite et al. 2010, Nelson \& Schrock 2006, Niederl \& Narodoslawsky 2004, Ozata et al. 2008, Peiro et al. 2010, Pleanjai 2009, UK Department of Transport 2008, US EPA 2010, Xunmin et al. 2009, Zah et al. 2007), however, none of these have addressed the GHG emissions from the use of poultry fat (PF) for biodiesel. The purpose of this study is to assess what will most likely happen in terms of emitted GHG if it is chosen to use PF for making biodiesel used in transportation. In order to answer this question, a case study focusing on well-to-wheel GHG emissions caused by the production and use of $1 \mathrm{~kg}$ of PF biodiesel in the US, is performed.

\section{Method}

This study follows the steps in a life cycle assessment (LCA), being goal and scope definition, inventory, and impact assessment (JRC 2010). These steps will be addressed below.

\section{1 Goal and scope definition}

The purpose of this study is as noted to answer the question: What will happen in terms of emitted GHG if PF is used for making biodiesel used in transportation? When 'something happens' it can be understood as a change from a baseline situation. Thus, by this question we are interested in assessing the difference in GHG emissions from the baseline scenario in comparison to a 'new situation', which can be expressed as the difference in terms of emitted GHGs between a situation where PF is used for production and use of biodiesel and the baseline situation where it is not.

An obvious obstacle in answering this question is, however, that at least one of the mentioned situations are going to be counterfactual, and that the assessment therefore by nature will have a speculative character. Yet, if we are interested in answering the question stated above, this is an issue which cannot be avoided by any methodological 'tricks'.

As the GHG emissions arise from the processes included in the assessment, to identify the change in GHG emissions the processes that change as a result of the use of PF for biodiesel need to be identified. The processes that change will depend on production and market conditions. In this assessment, it was chosen to use existing production and market 
conditions in the US. Given that these change relatively rapidly over time in the biodiesel sector, the assessment should only be considered valid within the next few years.

In the following the changes that are expected most likely to occur as a result of the use of PF for biodiesel, are outlined.

Literature on what PF is used for, if not for biodiesel is scarce. Literature suggests that animal fats in general are most likely used in the feed industry (López et al. 2010, Meeker 2009), and that PF is often used in poultry feed (Firman 2006, Groschen 2002). Thus, in this assessment it is assumed that if PF is not used for biodiesel, it will be used in poultry feed. In this connection a question which arises is whether an increase in demand for PF from biodiesel producers will simply increase the production of PF to meet the new demand or whether its use for biodiesel will incline feed producers to find a substitute. We assume that due to the low value of PF in comparison to the meat production, an increase in the demand and thereby price of PF will not lead the poultry farmers to increase their production of poultry and thereby PF. For other rendered fats, this assumption is supported elsewhere (Stiefelmeyer et al. 2006).

It is thus assumed that if the PF is used for biodiesel, this will most likely lead feed producers to find a substitute rather than make poultry farmers produce more poultry. This implies that as no changes in the production of poultry are expected no emissions related to the production of poultry are included in the assessment.

Biodiesel is, however, not made from oil alone, but depends also on inputs of methanol and various chemicals and energy. Biodiesel may be made through different processes, which will affect both needed inputs and produced outputs. Two options are considered; a batch transesterification process of PF and methanol using potassium hydroxide as a catalyst; and a similar process but including an esterification step before the transesterification where the free fatty acid content in the PF is converted to biodiesel using sulfuric acid as a catalyst. Regardless of the approach used, we have assumed that the use of methanol, chemicals and energy will result in additional production of these goods by marginal ${ }^{1}$ producers. In most cases these are considered to be the average producers, as differences in GHG emissions between marginal and average technologies are assumed to be small, however, when it comes to electricity, this assumption does not hold (Ekvall \& Weidema 2004). Due to the complexity in identifying the marginal electricity production (Lund et al. 2010) two different scenarios are considered; one where the electricity is based on coal, the other on natural gas. Both biodiesel processes result in the production of biodiesel, glycerol and some 'lost biofuel', which is mainly a mix of biodiesel, glycerol and ethanol (Burton 2011).

With regards to the outputs from the biodiesel production, the production of biodiesel is assumed to be used for transportation instead of petrochemical diesel, displacing both its production and use.

The glycerol is more difficult, as it is somewhat unclear what additional glycerol on the market would imply. First of all, it may substitute petrochemical glycerol (Malca \& Freire 2011; JRC 2007). This scenario is, however, not considered very likely, due to the large production of glycerol from biodiesel production and the relatively low demand for petrochemical glycerol (JRC 2007). Within the chemical industry the most economically attractive use has been claimed to be the production of propylene glycol (PG) (1,2 and 1,3-propanediol) from glycerol (Pagliaro \& Rossi 2010; JRC 2007). A problem with this assumption is, however, that to our knowledge very few companies perform this process today, and given the short time span of the assessment, it is questionable whether the production capacity will increase within this period. Purified glycerol may also be used in the feed industry (Malca \& Freire 2011; Bauen et al. 2010) substituting energy from carbohydrates. Finally, it may also be used unpurified in boilers, substituting petrochemical fuel (JRC 2007), but this solution is not very economically attractive (JCR 2007). Which of these can be considered the most likely scenario, is difficult to assess. We have chosen to consider the use of glycerol in the production of PG or as feed in the main scenarios. However, to assess the importance of these assumptions about glycerol in more depth, the two other possibilities are included in the discussion of the results.

The mentioned 'lost biofuel' is assumed to be used in an industrial boiler (Burton 2011), thereby displacing the production and use of fuel oil.

To summarise, the most likely changes incurred if PF is used for biodiesel in comparison to the baseline situation where it is not, are found to be the following:

\begin{tabular}{|l|l|l|}
\hline Baseline & New situation & Change \\
\hline -Use of PF in feed & $\begin{array}{l}\text {-Use of PF in the } \\
\text { production of biodiesel }\end{array}$ & $\begin{array}{l}\text { Increased production of biodiesel (1). } \\
\text { Increased production of substitutes in feed (2) }\end{array}$ \\
\hline -Driving on diesel & -Driving on biodiesel & $\begin{array}{l}\text { Decreased production of diesel (increased production } \\
\text { of biodiesel included above) and changes in the } \\
\text { emission profile of car (3) }\end{array}$ \\
\hline
\end{tabular}

\footnotetext{
${ }^{1}$ The marginal product is defined as the product which will change in supply due to changes in demand.
} 


\begin{tabular}{|l|l|l|}
\hline $\begin{array}{l}\text {-Use of petrochemical PG, } \\
\text { or use of energy feed }\end{array}$ & $\begin{array}{l}\text {-Use of PG made from } \\
\text { biodiesel glycerol, or } \\
\text { use of glycerol from the } \\
\text { production of biodiesel }\end{array}$ & $\begin{array}{l}\text { Decreased production of petrochemical PG and } \\
\text { increase in the production of PG from biodiesel } \\
\text { glycerol (4), or } \\
\text { decreased production of energy feed (5) }\end{array}$ \\
\hline $\begin{array}{l}\text {-Use of light fuel in } \\
\text { industrial boiler }\end{array}$ & $\begin{array}{l}\text {-Use of lost biofuel from } \\
\text { the production of biodiesel }\end{array}$ & $\begin{array}{l}\text { Decreased production of light fuel oil for industrial } \\
\text { boiler and change in the emission profile of boiler (3). }\end{array}$ \\
\hline
\end{tabular}

Table 1: Changes created by the use of PF for biodiesel. Numbers refer to the sections below where the changes are described and the resulting GHG emissions calculated.

The outlined 2 different ways of producing biodiesel, 2 ways of utilizing glycerol from biodiesel, and the 2 different electricity supplies in total make up 8 possible scenarios, all of which are included in the following assessment.

When calculating the GHG emissions related to these changes, we are not using the often used 'accounting principle' of 'biogenic' GHG emissions. Even though this is fully possible to utilize and very practical in many situations, it will in this case easily give some confusion in relation to the set boundaries. Rather, to keep the assessment as simple as possible, we will simply focus on the emissions and absorptions of GHGs that the changes outlined above will create. It should, however, be emphasized that regardless which 'accounting principles' are used, the results should obviously be the same.

\subsection{Inventory and impact assessment}

Below, each of the listed changes in table 1, will be described in more detail in order to assess the resulting changes in $\mathrm{GHG}^{2}$ emissions. Changes in transportation are considered for each change.

\subsubsection{Increased production of PF biodiesel (1)}

As mentioned above, two different PF biodiesel production processes are considered. One is a common batch transesterification process using potassium hydroxide as a catalyst. Due to the content of free fatty acids (FFA) in the $\mathrm{PF}$, this process results in some soap formation, which in our case company is washed out with the waste water (Burton 2011). The other process is similar, but includes an esterification process of the PF before the transesterification step. The esterification process is made to esterify the FFA to biodiesel, thereby avoiding the soap formation, using sulphuric acid as a catalyst.

Data for the transesterification process is based on data obtained from Piedmont Biofuels (Burton 2011), a biodiesel producer operating in Pittsboro, NC, in the US. As this facility does not include an esterification process, the data for this is based on literature (Canakci \& Gerpen 2003). Also, as the facility does not include a facility for distillation of the glycerol, data from a biodiesel producer in Denmark (Gordon 2011), was used for the scenarios demanding pure glycerol. Piedmont Biofuels has not had any problems keeping below the sulfur content limits, and no desulphurization process is therefore included. The resulting GHG emissions are calculated on the basis of standard process data (Ecoinvent 2007).

\begin{tabular}{|l|l|l|}
\hline Inputs & Quantity & $\begin{array}{l}\text { GHG emission } \\
\text { (kg CO }_{2} \text { eq.) }\end{array}$ \\
\hline Transesterification & & \\
\hline PF & $1.16 \mathrm{~kg}$ & \\
\hline Methanol & $0.224 \mathrm{~kg}$ & 0.167 \\
\hline Potassium hydroxide & $0.00996 \mathrm{~kg}$ & 0.0197 \\
\hline Electricity & $0.157 \mathrm{kWh}$ & $0.187 ; 0.107$ \\
\hline Process water & $0.782 \mathrm{~kg}$ & 0.000249 \\
\hline Biodiesel plant & $8 \mathrm{e}-10 \mathrm{pcs}$ (Est.) & 0.00197 \\
\hline $\begin{array}{l}\text { Transportation of chemicals } \\
\text { and methanol }\end{array}$ & $48 \mathrm{~kg} * \mathrm{~km}$ (Est.) & 0.00929 \\
\hline Glycerol purification & & \\
\hline Sodium hydroxide (50\%) & $0.00413 \mathrm{~kg}$ & 0.00478 \\
\hline Hydrochloric acid (30\%) & $0.00785 \mathrm{~kg}$ & 0.00721 \\
\hline Process steam & $0.153 \mathrm{MJ}$ & 0.0124 \\
\hline
\end{tabular}

\footnotetext{
2 The characterization factors for GHGs are based on the IPCC fourth assessment revision report (Fosters \& Ramaswamy 2007).
} 


\begin{tabular}{|l|l|l|}
\hline Electricity & $0.004 \mathrm{kWh}$ & $0.00476 ; 0.0027$ \\
\hline Esterification (of 2 \% FFA) & $1.23 \mathrm{e}-3 \mathrm{~kg}$ & $1.74 \mathrm{e}-4$ \\
\hline Sulphuric Acid & $3.01 \mathrm{e}-3 \mathrm{~kg}$ & 0.00225 \\
\hline Methanol & $1.09 \mathrm{e}-2 \mathrm{~kg}$ & 0.0299 \\
\hline Natural gas (heating) & $1.25 \mathrm{e}-2 \mathrm{kWh}$ & $0.0149 ; 0.0085$ \\
\hline Electricity & $0.85 \mathrm{~kg}$ *km (Est.) & $1.64 \mathrm{e}-4$ \\
\hline $\begin{array}{l}\text { Transportation of chemicals } \\
\text { and methanol }\end{array}$ & & \\
\hline $\begin{array}{l}\text { Outputs - } \\
\text { Transesterification only }\end{array}$ & $1.00 \mathrm{~kg}$ & \\
\hline Biodiesel & $0.106 \mathrm{~kg}$ & \\
\hline Glycerol (>98\% purity) & $0.256 \mathrm{~kg}$ & \\
\hline $\begin{array}{l}\text { Lost biofuel (0.164 kg lost } \\
\text { biodiesel, 0.0127 kg glycerol } \\
\text { and 0.0802 kg methanol) }\end{array}$ & $0.782 \mathrm{~kg}$ & 0.00258 \\
\hline Waste water for treatment & & \\
\hline $\begin{array}{l}\text { Outputs - Esterification and } \\
\text { transesterification }\end{array}$ & $1.02 \mathrm{~kg}$ & \\
\hline Biodiesel & $0.106 \mathrm{~kg}$ & \\
\hline Glycerol (>98\% purity) & $0.256 \mathrm{~kg}$ (Calc.) & \\
\hline Lost biofuel (as above) & $0.762 \mathrm{~kg}$ & 0.00251 \\
\hline Waste water for treatment & \\
\hline
\end{tabular}

Table 2: Inputs and outputs from the production of PF biodiesel and resulting GHG emissions. The two emissions for electricity refer to power produced from coal and natural gas. 'Est.' implies that the value is estimated, and 'calc' that the value is calculated on the basis of stoichiometry.

Transportation of the PF to the biodiesel facility is assumed to be the same as the transport would have been if the PF had been transported to the feed producing facilities. The same is the case for the transport of the PF biodiesel to the customers, which is assumed to be the same as the transport of the petrochemical diesel from the refineries to the end customers in the baseline scenario. In the same way, the transportation of glycerol and lost biofuel to the end consumers are not considered to lead to any additional transportation, too. The added transport above therefore relates only to the transportation of the included chemicals and methanol.

\subsubsection{Increased production of alternative feed products (2)}

To analyze how the composition of the poultry feed is changed when not including PF a simulation based on least cost feed optimization (Bestmix Feed Formulation Software, version 3.16) was made. Input for this simulation was prices of feed ingredients, and a restriction of maximum 20 and $25 \mathrm{~g} / \mathrm{kg}$ of linoleic acid (C18:2) per $\mathrm{kg}$ feed. The content of linoleic acid is limited as even though a high content may improve digestibility and consequently the energetic value, which is an advantage, especially for young animals with limited digestive capacity, the drawback of high unsaturated fatty acid content is the risk of soft fat in broilers at slaughter.

The results showed that the total fat content in the feed remained very constant when PF was removed from the feed, through the increased input of other fat sources. Usable alternatives were assumed to be palm oil and soybean oil. Firman (2006) states that apart from these two oils, sunflower oil is also commonly used in poultry feed. However, due to its higher price, this oil was not considered. The feed simulation showed that for each $\mathrm{kg}$ of PF removed from the feed, an input of $0.67 \mathrm{~kg}$ of palm oil and $0.34 \mathrm{~kg}$ of soybean oil was required, regardless of which limit of linoleic acid in the feed was used. These amounts may be affected by changes in the price of the fats or the energetic value used in the feed, however, the conclusion that PF is replaced by other fats without significant changes in the rest of the diet composition was stable in the simulations. As a small comment, it is interesting to note that the substitution of the PF calls for the production of almost the exact same amount of other types of oil, which are also frequently used for biodiesel. If all other things were equal this would imply that results equal to those of biodiesel based on palm or soybean oil could be expected from this study.

The emissions related to the production and transport of palm and soybean oil are outlined below:

\begin{tabular}{|l|l|l|l|l|l|l|}
\hline Oil & Production $(\mathrm{kg}$ & $\begin{array}{l}\text { LUC } \\
\text { emissions } \\
\text { CO2 eq./ kg } \\
\text { oil) }\end{array}$ & $\begin{array}{l}\text { C absorption } \\
\text { during growth } \\
\text { (kg CO2 eq./ }\end{array}$ & $\begin{array}{l}\text { Transportation } \\
\left(\mathrm{kg} \mathrm{CO}_{2} \text { eq./kg }\right. \\
\text { oil) }\end{array}$ & $\begin{array}{l}\text { Needed oil to } \\
\text { displace } 1.16 \mathrm{~kg} \\
\mathrm{PF}(\mathrm{kg} \text { oil })\end{array}$ & $\begin{array}{l}\text { Total emission } \\
\text { to displace } 1.16 \\
\mathrm{~kg} \mathrm{PF}(\mathrm{kg} \mathrm{CO}\end{array}$ \\
\hline
\end{tabular}




\begin{tabular}{|c|c|c|c|c|c|c|}
\hline & & kg oil) & oil & & & eq./kg oil) \\
\hline Palm: & $\begin{array}{l}0.595 \\
\text { (Souza et al. } \\
2010)\end{array}$ & $\begin{array}{l}2.06 \\
\text { (Croezen et } \\
\text { al. 2010) }\end{array}$ & $\begin{array}{l}2.81 \text { (calc. from } \\
\text { Metha \& Anad } \\
\text { 2009) }\end{array}$ & $0.152^{3}$ & 0.777 & \multirow[t]{2}{*}{0.167} \\
\hline Soy: & $\begin{array}{l}1.16 \\
\text { (Ecoinvent } \\
2007) \\
\end{array}$ & $\begin{array}{l}2.03 \\
\text { (Croezen et } \\
\text { al. 2010) }\end{array}$ & $\begin{array}{l}2.84 \text { (calc. from } \\
\text { Metha \& Anad } \\
\text { 2009) }\end{array}$ & $0.0745^{3}$ & 0.394 & \\
\hline
\end{tabular}

Table 3: GHG emissions related to the production of palm and soybean oil needed to substitute $1.16 \mathrm{~kg}$ PF.

\subsubsection{Increased or decreased production and use of fuel oil and diesel (3)}

As outlined in table 1 above, biodiesel will substitute diesel, and lost biofuel will substitute fuel oil. The substitution of fuel amounts are in both cases made on a one-to one energy (LHV) basis. In relation to the substitution of diesel with PF biodiesel, this assumption is supported in literature (Lapuerta et al. 2008). No literature addresses the efficiency of substituting fuel oil with the lost biofuel, however, the potential inaccuracy introduced by this assumption will be very limited. Below a table summarizes the substituted amounts and the resulting GHG emissions. The GHG emissions are calculated by summing the emissions from production and use of the fuels. The GHG emission from the use of the fuels will vary as the chemical composition of e.g. diesel and biodiesel differs. This difference in emissions from the use is calculated through first calculating the mass of the substitutes. Then the carbon content of each of these masses is calculated based on average molecular structure and converted to $\mathrm{CO}_{2}$, and the numbers for the substituting and the substituted fuel are subtracted. The numbers below show the total GHG emission, including production and use emissions. Emissions from the production are based on standard process data (Ecoinvent 2007).

\begin{tabular}{|c|c|c|c|c|c|c|}
\hline Substitution & Fuel & $\begin{array}{l}\text { Energy } \\
\text { content } \\
(\mathrm{MJ} / \mathrm{kg})\end{array}$ & $\begin{array}{l}\text { Masses } \\
\text { substituted } \\
(\mathrm{kg})\end{array}$ & $\begin{array}{l}\text { Carbon content } \\
\text { (w. C/w. total) }\end{array}$ & $\begin{array}{l}\text { Production } \\
\text { (kg } \mathrm{CO}_{2} \text { eq.) }\end{array}$ & $\begin{array}{l}\text { Total GHG } \\
\text { emission (kg } \\
\mathrm{CO}_{2} \text { eq.) }\end{array}$ \\
\hline \multirow{2}{*}{$\begin{array}{l}\text { Diesel with } \\
\text { PF biodiesel }\end{array}$} & Diesel: & 42.5 & 0.886 & 0.861 & 0.531 & \multirow[t]{2}{*}{-0.50} \\
\hline & PF biodiesel: & 37.7 & 1 & 0.771 & Incl. above & \\
\hline \multirow{2}{*}{$\begin{array}{l}\text { Fuel oil with } \\
\text { lost biofuel }\end{array}$} & Fuel oil: & 44.6 & 0.181 & 0.861 & 0.088 & \multirow[t]{2}{*}{-0.070} \\
\hline & Lost biofuel: & 31.5 & 0.256 & 0.628 & Incl. above & \\
\hline
\end{tabular}

Table 4: GHG emissions from substitutions and use of fuels. Negative total GHG emissions indicate that using biodiesel or lost biofuel instead of diesel or fuel oil lowers emissions.

Transportation distances from the poultry rendering plant or biodiesel plant to the user is assumed equal to the distances from the refinery to the user. Therefore, no changes in emissions from transportation are assumed.

\subsubsection{Glycerol used in the production of PG (4)}

As mentioned above, glycerol can be used in the production of PG, and is thereby assumed to substitute petrochemically produced PG. The production of PG from glycerol includes a catalytic dehydration to acetol and a catalytic hydrogenation and distillation to PG (Pagliaro \& Rossi 2010). No standard data for this process could be found, so an estimate of the related GHG emissions based on the included processes was performed. The glycerol is heated to $200{ }^{\circ} \mathrm{C}$ (from an assumed ambient temperature of $20^{\circ} \mathrm{C}$ ) under close to atmospheric pressure (Pagliaro \& Rossi 2010). The heating is assumed to be performed by natural gas with $90 \%$ efficiency. With a specific heat of 2.4 $\mathrm{kJ} /(\mathrm{kg} \mathrm{K})$ and a mass of $0.106 \mathrm{~kg}$ glycerol, this gives an emission of $0.0035 \mathrm{~kg} \mathrm{CO}_{2}$ eq (Ecoinvent 2007). The resulting acetol is hydrogenated using $1 \mathrm{~mol}$ of $\mathrm{H}_{2}$ per mol of acetol, resulting in $0.0047 \mathrm{~kg} \mathrm{CO}_{2}$ eq (Ecoinvent 2007). Finally, the PG is distilled, using natural gas, as before. Assuming no energy for cooling and a heat of evaporation of $67 \mathrm{~kJ} / \mathrm{mol}$, this results in an emission of $0.0071 \mathrm{~kg} \mathrm{CO}_{2}$ eq (Ecoinvent 2007). The petrochemical production of $0.106 \mathrm{~kg}$ PG results in $0.441 \mathrm{~kg} \mathrm{CO}_{2}$ eq (Ecoinvent 2007). Substituting petrochemical PG with PG based on glycerol thereby results in a saved emission of $0.426 \mathrm{~kg} \mathrm{CO}_{2}$ eq. It should be noted that in reality the saved emissions is probably a little lower, as the

\footnotetext{
${ }^{3}$ The emissions from transportation are based on the assumption that the palm oil comes from SE Asia. In SE Asia, the average distance from the oil mill to the harbor is assumed to be $500 \mathrm{~km}$ on rail. Sailing distances from SE Asia across the Atlantic Ocean to the US east coast, is estimated to be $19,000 \mathrm{~km}$. The east coast rather than the west coast is chosen because the biofuel plant used in this case study is located close to the east coast (see section 2.2.1) and because the PF displaced is assumed to be produced relatively close to the biofuel plant, implying that palm oil transported to the west coast would not be able to substitute PF close to the east coast without being transported across the US, which is considered less likely. The distance from the US east coast harbor to the biodiesel plant is $500 \mathrm{~km}$, which is done by rail. Soybean oil is assumed to be produced in the in the largest soybean producing states in the US, calling for around $1500 \mathrm{~km}$ of transportation by rail to the feed producer.
} 
production is assumed to run at a $100 \%$ efficiency in terms of hydrogen input and without the use of auxiliaries, such as catalysts and electricity. The transport of the petrochemical PG and the PG based on glycerol are assumed to be equal and thereby not lead to any changes in GHG emissions.

\subsubsection{Glycerol substituting feed (5)}

A second possibility mentioned in literature is the use of glycerol as energy feed. The marginal energy feed is assumed to be wheat (Bauen et al. 2010). $1 \mathrm{~kg}$ of glycerol has been reported to have the same feed energy as $0.938 \mathrm{~kg}$ of wheat (Jonasson \& Sandén 2004).

GHG emissions related to the production of wheat is assumed to be $0.685 \mathrm{~kg} \mathrm{CO}_{2}$ eq./kg (Ecoinvent 2007). The average land use change emissions related to the production of wheat is $0.443 \mathrm{~kg} \mathrm{CO}_{2}$ eq./kg (Croezen et al. 2010) (calculated from land use change emissions from wheat ethanol (Bernesson et al. 2006), using a 20 year amortization period). The uptake of $\mathrm{CO}_{2}$ during growth is around $1.58 \mathrm{~kg} \mathrm{CO}_{2} / \mathrm{kg}$ wheat (carbon content is around $43 \%$ (Merah et al. 1999)). In total, the production of $1 \mathrm{~kg}$ of wheat absorbs $0.452 \mathrm{~kg} \mathrm{CO}_{2}$. Assuming that the GHG emissions from the livestock are equal whether they are fed with wheat or glycerol, this implies that substituting $0.106 \mathrm{~kg}$ of glycerol with wheat results in an emission of $0.0449 \mathrm{~kg} \mathrm{CO}_{2}$ eq. The transportation of the glycerol and the wheat is assumed to be equal.

\section{Results}

Based on the above findings 8 different scenarios have been developed by combining in all possible ways each of the two outcomes for each of the 3 scenario variables; the two different uses of the glycerol resulting from the production of biodiesel, the two different biodiesel production processes, and the two different marginal electricities.

The results for these scenarios are shown below.

\begin{tabular}{|c|c|c|c|c|c|c|c|c|}
\hline Scenario variable & $\begin{array}{l}\text { Scenaric } \\
\text { negative }\end{array}$ & $\begin{array}{l}\text { Imber } \\
\text { Imber }\end{array}$ & $\begin{array}{l}\text { d GH } \\
\text { licate }\end{array}$ & $\begin{array}{l}\text { missic } \\
\text { ing) }\end{array}$ & er kg & biodies & (kg CC & \\
\hline & 1 & 2 & 3 & 4 & 5 & 6 & 7 & 8 \\
\hline Feed substitute PF & 0.16 & 0.16 & 0.16 & 0.16 & 0.16 & 0.16 & 0.16 & 0.16 \\
\hline $\begin{array}{l}\text { Glycerol used for PG and substitute pet. } \\
\text { PG, no purification of glycerol }\end{array}$ & -0.43 & & -0.43 & & -0.43 & & -0.43 & \\
\hline Glycerol substitute feed & & 0.04 & & 0.04 & & 0.04 & & 0.04 \\
\hline $\begin{array}{l}\text { Biodiesel production includes } \\
\text { esterification, coal }\end{array}$ & & & 0.46 & 0.49 & & & & \\
\hline $\begin{array}{l}\text { Biodiesel production excludes } \\
\text { esterification, coal }\end{array}$ & 0.39 & 0.42 & & & & & & \\
\hline $\begin{array}{l}\text { Biodiesel production includes } \\
\text { esterification, natural gas }\end{array}$ & & & & & & & 0.37 & 0.40 \\
\hline $\begin{array}{l}\text { Biodiesel production excludes } \\
\text { esterification, natural gas }\end{array}$ & & & & & 0.31 & 0.34 & & \\
\hline Biodiesel substitute diesel & -0.50 & -0.50 & -0.50 & -0.50 & -0.50 & -0.50 & -0.50 & -0.50 \\
\hline Biofuel substitute fuel oil & -0.07 & -0.07 & -0.07 & -0.07 & -0.07 & -0.07 & -0.07 & -0.07 \\
\hline Total & -0.45 & 0.05 & -0.38 & 0.12 & -0.53 & -0.03 & -0.47 & 0.03 \\
\hline $\begin{array}{l}\text { Compared to driving on diesel }{ }^{4}(\%) \\
\text { (negative number indicate saving) }\end{array}$ & -13 & 2 & -11 & 4 & -16 & -1 & -14 & 1 \\
\hline
\end{tabular}

Table 5: Well-to-wheel GHG emissions for the use of PF biodiesel. The table shows the 8 included scenarios, developed by varying the 3 scenario variables in all possible ways. A number in a cell indicates that a certain outcome of a scenario variable is considered for the given scenario number. For example, in scenario 1, it is assumed that the produced glycerol will substitute PG; that the electricity used in the biodiesel process is based on coal; and that the biodiesel production does not include an esterification process. Furthermore, as all scenarios, scenario 1 includes emissions related to the substitution of PF, the substitution of diesel with PG biodiesel, and the substitution of fuel oil with 'biofuel'. A total emission of zero would indicate that there are no difference in the total emissions from the baseline situation and the new situation where PF is used for biodiesel. Negative numbers indicate avoided emissions.

\footnotetext{
${ }^{4}$ The well-to-wheel emission from the combustion of $1 \mathrm{MJ}$ of diesel in a car engine is $0.0896 \mathrm{~kg} \mathrm{CO}_{2}$ eq. (Ecoinvent 2007). One kg of PF biodiesel contains 37.7 MJ. To obtain 37.7 MJ of energy from diesel results in $3.38 \mathrm{~kg} \mathrm{CO}_{2}$ eq.
} 
The 'total' for each scenario fluctuates around an average of $-6 \%$, indicating that the total emissions in the 'new situation' where PF is used for biodiesel are on average slightly lower than in the baseline situation (where the PF is used for original purposes and petrochemical diesel is used). This implies that according to this assessment, using PF in the production of biodiesel does in most assessed cases lead to a small reduction in GHG emissions. Using PG biodiesel will in the most positive scenario above reduce emissions by $15 \%$ in comparison to driving on petrochemical diesel ${ }^{4}$, in the most negative scenario lead to an increase in GHG emissions of $4 \%$.

The variation between the scenarios is mainly explained by what the glycerol substitutes. From the most positive to the most negative case, this results in difference of $15 \%$ in comparison to driving on diesel. Which of these substitutions is the most likely, however, is difficult to assess as the various solutions to the utilization of the glycerol produced in the biodiesel production are still being analyzed (Pagliaro \& Rossi 2010).

The results also point to that the increased efficiency of the process by including an esterification process in this case does not fully compensate the increase in GHG emissions from the increased use of chemicals and energy in the biodiesel production process. However, it should be mentioned that sulphuric acid esterification is normally done for oils with higher content of FFA than the PF used in this study, and in these cases, the situation may be different. Whether the electricity input to the biodiesel production is based on coal or natural gas shows to have a relatively small but noticeable effect. The emissions from the 'natural gas' scenarios have around 2\% lower GHG emissions than scenarios based on coal.

Besides the variation in the scenario results, there are significant uncertainties related to several of the emissions included in this assessment. A major uncertainty relates to the land use change emissions from the production of palm and soybean oil and, to a lesser extent, wheat. This study has used average values from literature with a 20 year amortization period. Varying these land use change emissions, both through using maximum and minimum reported emissions (Croezen et al 2010), and through the use of a 30 year amortization period, which is often used in US studies, the final results from scenario 2 would vary from $25 \%$ to $-37 \%$ in comparison to driving on diesel.

A second uncertainty relates, as mentioned above, to what the glycerol from biodiesel will actually substitute. To analyze the importance of this uncertainty in more depth, we have included the potential substitution of petrochemical glycerol and power plant fuel with glycerol. If substituting petrochemical glycerol on a one-to-one weight basis, and using standard process data (Ecoinvent 2007) the final results in scenario 1 would be $-16 \%$ (instead of $-13 \%$ ) in comparison to driving on diesel. If on the other hand glycerol substitutes fuel oil in power plants on a one-to-one LHV basis using standard process data (Ecoinvent 2007) the final results in scenario 2 would be $1 \%$ lower (i.e. 1\% in comparison to driving on diesel). What glycerol substitutes can thereby make a significant difference, but this shows that the inclusion of these additional substitution possibilities does only slightly add to the variation already considered in the scenarios above.

Changes in the efficiency of the process may also influence the results significantly. Comparing to a $100 \%$ efficient process, here understood as a process where all oil is either converted to biodiesel and glycerol in proportionate amounts and the input of methanol is based on stoichiometric calculations, the results would be lowered by around $5 \%$ in comparison to driving on diesel due to the lowered input of oil, and by $3 \%$ due to the lowered consumption of methanol. However, at the same time, no lost biofuel would be produced, as it is only produced when the biodiesel production is not running with 100\% efficiency. And as the lost biofuel substitutes fuel oil, this lowered output of lost biofuel would increase the total emission of $2 \%$, giving a reduction potential of around $6 \%$ in total. This potential may be lowered by $1 \%$ extra if also considering the potential use of catalyst residue as a fertilizer, as considered in Jensen et al. (2007). If also using the somewhat lower power consumption considered by Jensen et al. (2007) an additional $1 \frac{2}{2} \%$ may be gained. In total, this implies that a fully optimized process could decrease the GHG emissions by around $7.5 \%$ in comparison to driving on diesel.

Another and much smaller uncertainty relates to the assumptions about transportation of the palm and soybean oils in section 2.2.2. Here it was among other assumed that the palm oil in SE Asia is transported $500 \mathrm{~km}$ by rail to the harbor. As this may vary quite significantly, a doubling and halving of the distance was considered. The other distances included are considered to be more robust, given the explanations in section 2.2.2. Incorporating this lower demand for transportation in scenario 1 will lower the emissions by $0.2 \%$ in comparison to driving on diesel, whereas incorporating the higher transport demand will increase the emission by $0.4 \%$.

This indicates that in an absolute best case, using minimum land use change emissions, a fully optimized process, best substitution of glycerol, and minimizing transportation the result in scenario 5 would be -64\% in comparison to driving on diesel. Similarly, in the 'worst case', where the efficiencies of the process are as presented in this study, where the transportation demand is high, and where land use change emissions are at a reported maximum, the emissions in scenario 4 would be $26 \%$ higher than when driving on diesel. However, as a comment to this, it should be noted that the emissions on which the scenarios in table 5 are based are considered average, and that the lower and upper value should be considered as 'extremes'. 
Besides these and several other uncertainties relating to the processes included in the scenarios, there are other and probably much larger uncertainties related to whether the futures considered in these scenarios will actually materialize. We have here assessed scenarios which are based on a variety of actual or earlier events, but despite our attempts to foresee different futures by combining these variations in different ways, the future often shows difficult to predict. Even though we have attempted to find the most realistic market responses, others than the ones considered here is therefore a possibility. How this can change the results is impossible to say.

\begin{abstract}
4 Discussion and conclusions
Many other LCAs on BPO have been performed, as mentioned in section 1, and where it is possible to compare, these studies often get to very different results. Several explanations may be given for these differences, such as different type of BPO used, geographical setting, process efficiencies, etc. However, a main difference is that in many studies the use of the BPO for biodiesel is considered not to lead to any substitutions. At the same time, when burned in the engine, the GHG emissions are assumed biogenic, and therefore zero. Had it been assumed in this study that the use of the BPO did not lead to any substitutions, the result in scenario 1 would be around $-101 \%$ in comparison to driving on diesel. These assumptions about substitutions are therefore very important for the results. Given that the use of BPO actually leads to an increased production of a substitute, as assumed in this study, and if the purpose of the study is to answer the "what happens if...?” type of question as addressed in this study, then these concerns need to be included in the assessment. Some may argue that this is only relevant if following a 'consequential LCA' and when applying an 'attributional LCA' approach these concerns do not need to be included. The terms 'attributional' and 'consequential' have deliberately not been used in this article. Rather than claiming to belonging to a certain 'LCA school', this article has simply attempted to answer the question: Is it beneficial in terms of GHG emissions to use PF biodiesel? If this is what the assessment attempts to answer then these very central emissions cannot be ignored simply by referring to a methodological choice. Considering that a central focus in the biodiesel debate is its potential to reduce GHG emissions, answering "what happens if...?” seems central. As argued above, in relation to BPO biodiesel this entails a consideration of the alternative use of BPO. Besides this study, this has only been done in two studies. Jensen et al. (2007) have assessed the GHG emissions from biodiesel made from rendered fats in general (reaching very similar results as found here when taking into account the differences in the cases), and Nelson \& Schrock (2006) assesses biodiesel made from beef tallow, but does not include GHG emissions. As several other types of BPO exist, this therefore seems as a relevant area for future research.
\end{abstract}

\title{
References
}

Bauen, A., Chudziak, C., Vad K., Watson, P., 2010. A causal descriptive approach to modeling the GHG emissions associated with the indirect land use impacts of biofuels. Department for Transport, London, UK

Beer, T., Grant, T., Campbell, P., K., 2007. The greenhouse and air quality emissions of biodiesel blends in Australia. Report Number KS54C/1/F2.27. Department of the Environment and Water Resources. Aspendale, Australia

Bernesson, S.; Nilsson, D.; Hansson, P. A. 2006. A limited LCA comparing large- and small-scale production of ethanol for heavy engines under Swedish conditions. Biomass Bioenerg. 30, 46-57

Burton, R., 2011. Communication with Research and Analytical Director at Piedmont Biofuels Industrial, Rachel Burton, Pittsboro, US

Canakci, M., Van Gerpen, J. 2003. A pilot plant to produce biodiesel from high free fatty acid feedstocks. Trans. ASAE 46, 945-954

Croezen, H. J., Bergsma, G. C., Otten, M. B. J., van Valkengoed M. P. J., 2010. Biofuels: Indirect land use change and climate impact. BirdLife International, Transport and Environment and the European Environmental Bureau, Delft, Holland

Ecoinvent, 2007. Ecoinvent database v2.0. Swiss Centre for Life Cycle Inventories. Dübendorf, Switzerland

Ekvall, T., Weidema B. P., 2004. System boundaries and Input Data in Consequential Life Cycle Inventory Analysis. Int. J. Life Cycle Assess. 9 (3), 161-171

Firman, J. D., 2006. Rendered products in poultry nutrition, in: Meeker, D. L. (Eds.), Essential Rendering: All About The Animal By-Product Industry. Kirby Lithographic Company, Inc. Virginia, US 
Fosters, P., Ramaswamy, V., 2007: Changes in Atmospheric Constituents and in Radiative Forcing. Second chanper in: IPCC Founrth Assessment Report: Climate Change 2007: Working Groun I: The Physical Science Basis. IPCC, Geneva, Switzerland

Gordon, K., 2011. Personal communication with Financial Manager at biodiesel producer Emmelev A/S, Kent Gordon, Otterup, Denmark

Groschen, R., 2002. The Feasibility of Biodiesel from Waste/Recycled Greases and Animal Fats. Minnesota Department of Agriculture. St. Paul, Minnesota, US

Jensen, K. H., Thyø, K. A., Wenzel, H., 2007. Life Cycle Assessment of Bio-diesel from Animal Fat. Institute for Product Development, Technical University of Denmark, Kgs. Lyngby, Denmark

Jonasson, K., Sandén, B., 2004. Time and Scale Aspects in Life Cycle Assessment of Emerging Technologies Case Study on Alternative Transport Fuels. Centre for Environmental Assessment of Product and Material Systems. Chalmers Univeristy of Technology, Gothenburg, Sweden

JRC, 2007. Well-to-whells analysis of future automotive fuels and powertrains in the European context. Well-to-wheels Report Version 2c, March 2007. European commission, Joint Research Centre, Brussels, Belgium

JRC, 2010. ILCD Handbook: General guide for Life Cycle Assessment - Detailed guidance. European Union. European Commission, Joint Research Centre, Brussels, Belgium

Lapuerta, M., Armas, O., Rodrigues-Fernandes, J., 2008. Effect of biodiesel fuels on diesel engine emissions. Prog Energ Combust. 34, 198-223

López, D. E., Mullins J. C., Bruce, D. A., 2010. Energy Life Cycle Assessment for the Production of Biodiesel from Rendered Lipids in the United States. Ind. Eng. Chem. Res. 49 (5), 2419-2432

Lund, H., Mathiesen, B. V., Christensen, P., Schmidt, J. H., 2010. Energy system analysis of marginal electricity supply in consequential LCA. Int. J. Life Cycle Assess. 15, 260-271

Malca, J., Friere F., 2011. Life-cycle studies of biodiesel in Europe: A review addressing the variability of results and modeling issues. Renew. Sust. Energ. Rev. 15, 338-351

Meeker, D. L., 2009. North American Rendering - processing high quality protein and fats for feed. R. Bras. Zootec. 38, 432-440

Merah, O., Delens, E., Monneveux P., 1999. Grain yield, carbon isotope discrimination, mineral and silicon content in durum wheat under different precipitation regimes. Physiol Plant 107, 287-394

Metha, P. S., Anad, K., 2009. Estimation of a Lower Heating Value of Vegetable Oil and Biodiesel Fuel. Energ Fuel. 23, 3893-3898

Morais, S., Mata, T. M., Martins, A. A., Pinto, G. A., Costa, C. A. V., 2010 Simulation and life cycle assessment of process design alternatives for biodiesel production from waste vegetable oils. J. Clean. Prod. 18, 1251-1259

Montrimaite, K., Staniškis, J. K., Lapinskiene, A. M., 2010. Potential of Greenhouse Gas Reduction Producing and Using Biodiesel from Fatty Waste. EREM 4 (54), 34-42

Nelson, R. G., Schrock, M. D., 2006. Energetic and economic feasibility associated with the production, processing, and conversion of beef tallow to a substitute diesel fuel. Biomass Bioenerg. 30 (6), 584-591

Niederl, A., Narodoslawsky, M., 2004. Life Cycle Assessment - study of Biodiesel from Tallow and Used Vegetable Oil. Institute for Resource Efficient and Sustainable Systems. Graz, Austria. 
Ozata, I., Ciliz, N., Mammadov, A., Buyukbay, B., Ekinci, E., 2008. Comparative Life Cycle Assessment Approach for Sustainable Transport Fuel Production from Waste Cooking Oil and Rapeseed. Istanbul Technical University, Chemical Engineering Department, Istanbul, Turkey

Pagliaro, R., Rossi, M., 2010. Future of Glycerol: $2^{\text {nd }}$ Edition Mario Pagliaro. Royal Society of Chemistry, London, UK

Peiro, L. T., Lombardi, L., Villalba Mendez, G., Gabarrell i Durany, X., 2010. Life cycle assessment (LCA) and exergetic life cycle assessment (ELCA) of the production of biodiesel from used cooking oil (UCO). Energy, 35, 889893

Pleanjai, S., Gheewala, S. H., Garivait, S., 2009. Greenhouse gas emissions from production and use of used cooking oil methyl ester as transport fuel in Thailand, J. Clean. Prod. 17, 873-876

Souza, S. P., Pacca, S., Avila, M. T., Borges J. L. B., 2010. Greenhouse gas emissions and energy balance of palm oil biofuel. Renew. Energ. 35, 2552-2561

Stiefelmeyer, K., Mussell, A., Moore, T., Liu, D., 2006. The Economic Impact of Canadian Biodiesel Production on Canadian Grains, Oilseeds and Livestock Producers. George Morris Centre, Guelph, Canada

UK Department for Transport, 2008. Carbon and Sustainability Reporting Within the Renewable Transport Fuel Obligation. Requirements and Guidance. Government Recommendation to the Office of the Renewable Fuels Agency. Department for Transport, London, UK

US EPA, 2010. Renewable Fuel Standard Program (RFS2) Regulatory Impact Analysis; Assessment and Standards Division Office of Transportation and Air Quality U.S. Environmental Protection Agency, Washington, US

Xunmin, O., Xiliang, Z., Shiyan, C., Qingfang, G., 2009. Energy consumption and GHG emissions of six biofuel pathways by LCA in (the) People’s Republic of China. Appl. Energ. 86, 197-208

Zah, R., Böni, H., Gauch, M., Hischier, R., Lehmann, M., Wäger, P., 2007. Life cycle assessment of energy products: Environmental assessment of biofuels. Federal Office of Energy, Environment and Agriculture. Bern, Germany. German title: Ökobilanz von energieprodukten: Ökologische bewertung von biotreibstoffen. 